\title{
Productive and Economic Viability of Raising Beef Cattle in the Savanna of the Brazilian State of Goiás ${ }^{1}$
}

\author{
Elis Regina de Oliveira ${ }^{2,3}$ and Victor Rezende Moreira Couto ${ }^{4}$
}

\begin{abstract}
The present study evaluates the economic viability of four different models of beef cattle production in the rio Vermelho hydrographic basin. The study focuses on the traditional extensive ranching system, which was compared to three intensive systems, one based on low levels of concentrated supplementation, a second with low levels of concentrated supplementation and confinement for fattening and an intensive grazing system, with supplementation during the dry and rainy seasons. The investments were estimated for the different levels of technical specifications of each system. The net present values and internal return rate were used for the assessment of the economic viability of the project, considering the minimum rate of attractiveness, equivalent to the inflation-adjusted savings interest rate $(6.17 \%)$. The continuity of the sector was evaluated based on the gross and net margins, and profitability rates, where the system is already installed. All four systems had gross and net margins and profitability consistent with their economic sustainability over both the short and long terms. However, only two systems (reduced consumption of concentrated supplements and the intensive grazing system) were economically viable as start-ups.
\end{abstract}

Key-words: economic viability, beef cattle ranching, production costs.

Resumo: O presente trabalho tem por objetivo analisar a viabilidade econômica de implantação de quatro modelos de sistema de produção de bovinos de corte. Foram considerados os sistemas: média da bacia hidrográfica do rio Vermelho, sistema de baixo consumo de suplemento concentrado, sistema de baixo consumo de suplemento com terminação em confinamento e sistema intensivo a pasto, com suplementação nos períodos de águas e de seca. Investimentos foram estimados conforme o nível de tecnificação de cada sistema. A análise de viabilidade econômica do projeto foi realizada com uso do valor presente líquido e a taxa interna de retorno, considerando-se a taxa mínima de atratividade equivalente ao juro real da poupança (6,17\%). Por meio da margem bruta, margem líquida e taxa de

Data de submissão: 29 de abril de 2016. Data de aceite: 29 de outubro de 2017.

1. We would like to thank Fausto R. Aguiar, Nilton R. Reis, Valdeci G. Silva, Breno Vaz, Elmon P. Oliveira, Fausto Miziara and Laerte G. Ferreira, who provided important contributions to the discussion on production systems. We are also grateful to Augusto A. Castro Junior and Stephen F. Ferrari for additional comments and improvements to this paper.

2. Universidade Federal de Goiás. Goiânia, Goiás, Brasil.

3. Pontifícia Universidade Católica de Goiás. Goiânia, Goiás, Brasil. E-mail: elisreg@gmail.com

4. Universidade Federal de Goiás. Goiânia, Goiás, Brasil. E-mail: victorzootecnista@hotmail.com 
lucratividade foi avaliada a permanência no setor, caso os sistemas já estejam instalados. Todos os sistemas apresentaram margem bruta, líquida e lucratividade que evidenciam a sustentabilidade econômica no curto e longo prazo, caso estejam implantados. No entanto, ao analisar o projeto para entrada no setor, apenas os sistemas de baixo consumo de suplemento concentrado e sistema intensivo a pasto apresentam viabilidade econômica.

Palavras-chaves: viabilidade econômica, pecuária de corte, custos de produção.

JEL Classification: Q13.

DOI: http://dx.doi.org/10.1590/1234-56781806-94790560302

\section{Introduction}

Demand for beef on both Brazilian and international markets is expected to grow progressively between 2015 and 2024, with prices rising by $4.4 \%$ per annum, providing an incentive for producers to increase their output. However, the capacity of the sector to respond to this increasing demand will depend on its ability to improve indices of productivity and install the infrastructure needed to improve the productive process. Where this capacity is limited, the production of pork or chicken may represent more viable alternatives (MAPA, 2014; ROBINSON et al., 2014; OECD-FAO, 2015).

In 2014, the Brazilian beef herd reached a total of 212.3 million head, up from 2013, produced on an estimated total of 72.33 million hectares, according the Brazilian Institute for Geography and Statistics (IBGE, 2015). Environmental pressures, the exhaustion of new agricultural frontiers, and the high demand for agricultural land all contribute to the intensification of beef production, with the ultimate objective of increasing the production of animal units per hectare (AU/ha) (ARMENTERAS et al., 2013; MAZZETTO et al., 2015; SILVA et al., 2016). This requires increasing efficiency through strategies such as genetic engineering, confinement during the final fattening phase, semi-confinement with supplementary feeding during the dry season, intensive supplementation of pasture, planning of the breeding season, and enhanced management of the soil, forage, and the animals (ABIEC, 2015). Understanding the economic viability of these measures, once adjusted to the current environmental legislation, will be essential for the development of new public policies for the improvement of productivity while maintaining environmental and economic sustainability. This knowledge will also be essential to the development of guidelines for the decision making of producers.

In Brazil, beef cattle production systems vary considerably among regions, according to local edaphic and climatic conditions, cultural traditions, and management practices (GARAGORRY et al., 2002; FELEMA and FERREIRA, 2013). Some beef producers apply modern technology and management techniques, leading to improvements in husbandry, such as reductions in the age at slaughter and the time to returns on investment. However, many other producers still use extensive ranching techniques that are low in productivity, and limit both the economic potential of the land and investments in the productive process.

This paper evaluated the productive and economic efficiency of four different systems of beef cattle production, which cover the complete cycle of production, and were based on four distinct levels of technological input in the context of the Brazilian Cerrado savanna biome, specifically the Rio Vermelho hydrographic basin in Goiás. The potential for the application of advanced production techniques depends on individual factors and their interactions, including edaphic and climatic conditions, the characteristics of the forage and animals, the institutional and management environments, and market forces (BELLAVER and BELLAVER, 1999; DILL et al., 2016).

In the present study, the parameters of productive efficiency that differentiated the four models included the rotation of pastures fertilized with different levels of nitrogen, low-level or intensive supplementation 
of grazing, confinement on site, and the creepfeeding of calves, which resulted in higher birth rates, animals with greater weaning weights, younger age at slaughter, reduction of the age of heifers at first birth, and reduced birth intervals. While the application of these parameters results in an increase in the volume of beef produced, it also involves an increase in costs and control levels, which make the activity more complex, requiring more time and management capability, in order to ensure adequate returns on the capital invested.

The study of economic viability through the net present value (NPV) and the internal return rate (IRR) permits the analysis of whether the investment in these systems is viable for new producers starting up in this sector. Indices of economic efficiency, such as the gross (GM) and net (NM) margins and profitability are used to evaluate the short and long-term viability of these activities, where these systems have already been established. These indices of economic efficiency provide a reference database for decision-making on production practices.

In Brazil, the economic assessment of projects for the implantation or maintenance of beef production systems has tended to emphasize extensive grazing systems, given the reduced costs of production and the long tradition of cattle ranching in Brazil. Based on the best management practices for beef cattle production, the percentage recovery (20-100\%) of areas of pasture, and high standards of husbandry, Martins et al. (2000) evaluated the economic viability of full-cycle beef production based on extensive grazing, obtaining a positive NPV for the more intensified systems, considering a minimum rate of attractiveness of $6.17 \%$ per annum, with a cash flow period of 12 years.

Simões et al. (2006) evaluated grazing-only systems based on their individual phases (breeding, rearing and fattening). The rearing phase returned the best results, while the fattening phase resulted in a net loss. Considering the risks and profitability, these results indicate that the complete-cycle production system has the lowest risks and medium-level profitability of the three phases.

Araújo et al. (2012) showed that extensive ranching can be viable, although this study was based on an existing beef production layout, without the need for investment in many aspects of the infrastructure required to raise beef cattle. All the indicators applied in this study (IRR, NPV, payback period, and the costbenefit ratio) indicated good levels of profitability, with receipts outstripping investment in seven years.

The present study is based on the analysis of the input necessary for the implantation of a full-cycle beef production system (breeding, rearing and fattening), with start-up investment in infrastructure, including fences, agricultural equipment, pasture seeding and maintenance, differentiated nitrogenous fertilization, installations for confinement, and supplementation, considering the specific requirements of each system, as well as the acquisition of the herd, maintained at the same levels throughout the project, with a total duration of 15 years.

\section{Materials and methods}

\subsection{Characteristics of the Rio Vermelho hydrographic basin}

The headwaters of the Rio Vermelho (the Red River) are located in the Serra Dourada, in the municipality of Goias, at an altitude of $830 \mathrm{~m}$ above sea level (upper basin). The river flows $440 \mathrm{~km}$ to its confluence at the right margin of the Araguaia River, at an altitude of $220 \mathrm{~m}$. The Araguaia then joins the Tocantins River to form the lower Tocantins-Araguaia basin (MACHADO and LIMA, 2011, VIEIRA, 2013).

The Rio Vermelho hydrographic basin covers a total area of $10,824.6 \mathrm{~km}^{2}$, and is located in western Goiás, a state of the Brazilian Midwest, including the whole of the municipality of Itapirapuã, and parts of a further 10 municipalities (Aruanã, Britânia, Buriti de Goias, Faina, Fazenda Nova, Goiás, Jussara, Matrinchã, Novo Brasil, and Santa Fé de Goiás). The whole of the basin is inserted within the Cerrado savanna biome of Central Brazil.

The region has two well-defined climatic seasons, a dry season, which peaks in July and August, and a rainy season, between December and March, with mean annual precipitation of $1500-1800 \mathrm{~mm}$ and mean temperatures of between $23{ }^{\circ} \mathrm{C}$ and $28^{\circ} \mathrm{C}$. The basin in dominated by red-yellow latosols (30.015\%) in level areas of up to $234 \mathrm{~m}$ in altitude, with cambisols (31.61\%) and litholic neosols (12.58\%) at higher altitudes. The soils are deeper in areas where the terrain is less inclined (VEIGA et al., 2012; SANTOS, 2014). 
The predominant soils in the Cerrado normally require investments in liming to correct their acidity and fertilizers to provide the nutrients required for the development of pastures (MARTHA JÚNIOR and VILELA, 2002; BALIEIRO NETO et al., 2006). Degraded pasture reduces the productive potential of the land, decreasing the availability of low-cost feed for the cattle. It also results in environmental liability, and it has been estimated that "less than $40 \%$ of the total area of pasture in Brazil" is in good or excellent conditions for grazing, and that $12 \%$ of existing pastures require immediate attention (FERREIRA et al., 2014, p. 135). Approximately $35 \%$ of the pastures planted in the Cerrado are currently degraded, with four Cerrado states, Mato Grosso do Sul, Mato Grosso, Goiás, and Minas Gerais (which are among the top five beefproducing Brazilian states), being responsible for $80 \%$ of the total area of degraded pasture in this biome in 2014 (ANDRADE et al., 2015).

Historically, cattle ranching is the traditional productive activity in the Rio Vermelho basin, and its principal economic activity, supporting the development of the local agribusiness, with $64 \%$ of the total area of the municipalities being covered by pasture (ESTEVAM, 1998; IBGE, 2006; PALACIN and MORAES, 2008). The study region has a network of paved highways, with distances of $142 \mathrm{~km}$ to 325 $\mathrm{km}$ to the state capital, Goiânia, although animals can be slaughtered at four meatpacking plants in the Rio Vermelho region (Aruanã-Frinan-SIE, JussaraMatadouro Goias-SIE; Santa Fé-Mataboi/JBS-SIF, and Goiás-JBS-SIF), or can be sold at other facilities in the municipalities of Mozarlândia, Goianira, Inhumas, Senador Canedo, and Goiânia (AGRODEFESA, 2015; MAPA, 2015).

Four distinct models of production were considered in the present study: 1) the traditional ranching system of the middle Rio Vermelho basin (TRV), which is characterized by average levels of productivity (in local and national terms), and the lowest level of technological development; 2) pasture with low levels of concentrated supplementation (PCS); 3) pasture with low levels of concentrated supplementation and confinement for fattening (SCF), and 4) Intensive Pasture System (IPS) with supplementation during the rainy and dry seasons for the whole herd, except for the cows and bulls in maintenance, which were only supplemented during the dry season.

\section{Parameters}

\subsection{Biophysical structure}

The same area of land (435.86 ha) was used for all the models in an area of flat terrain on the margins of the Rio Vermelho, divided into pasture (331.47 ha), forest reserve (87.17 ha), and an area of permanent preservation (9.69 ha), with the remaining areas dedicated to infrastructure, according to the biophysical characteristics of the middle Rio Vermelho basin. The pasture was divided into three fields in the TRV, 13 pickets in the PCS and SCF, and 20 in the IPS.

The estimated cost of fencing, with five strands of plain wire and posts at every six meters was $\mathrm{R} \$ 7119.79$ per kilometer. In the TRV, the fence posts were made of treated eucalyptus (Amaru) timber, while at the other three sites, the posts were made of Acapú hardwood.

The corral for the TRV had an estimated area of $256 \mathrm{~m}^{2}$, while the enclosures in the other systems had an area of $624 \mathrm{~m}^{2}$, including a holding pen and weighing scales for the safest and most efficient husbandry of the animals. The stockyards for confinement were constructed in timber, with a capacity for 154 animals, considering $30 \mathrm{~m}^{2}$ for each head of cattle. The estimates of the investment needed in infrastructure were based on the parameters shown in Table 1, which have been adjusted to the building style of the region, and including storage facilities for cattle feed and medication.

To minimize environmental impacts, a demand of 40 liters of water was projected for each animal unit (AU equivalent to $450 \mathrm{~kg}$ of body weight), for which nine Australian-type drinking troughs were included for the traditional ranching system (TRV), with 15 (PCS), 18 (SCF), and 14 (IPS) troughs for the other systems. Even so, standard practice in the region is to allow cattle access to local rivers and streams. Artificial water holes with a capacity sufficient for three days' supply $(60,120,150$, and 220 thousand liters) were also projected for each system.

The number of feeding troughs needed for each system was determined by the type of supplementation and the strategic distribution of the units in relation to the number of pickets and the size of the herd. Four $2.8 \mathrm{~m}$ metal troughs were projected for the TRV system, 13 for the PCS, 45 for the SCF, and 60 for the IPS. 
Table 1. Parameters of rural buildings

\begin{tabular}{l|cc|cc|cc|cc}
\hline \multirow{2}{*}{\multicolumn{1}{c|}{ Type of building }} & \multicolumn{2}{c|}{ TRV } & \multicolumn{2}{c|}{ PCS } & \multicolumn{3}{c|}{ SCF } & \multicolumn{2}{c}{ IPS } \\
\cline { 2 - 10 } & $\begin{array}{c}\text { Area } \\
\left(m^{2}\right)\end{array}$ & $\begin{array}{c}\text { Value } \\
\left(R \$ / m^{2}\right)\end{array}$ & $\begin{array}{c}\text { Area } \\
\left(m^{2}\right)\end{array}$ & $\begin{array}{c}\text { Value } \\
\left(R \$ / m^{2}\right)\end{array}$ & $\begin{array}{c}\text { Area } \\
\left(m^{2}\right)\end{array}$ & $\begin{array}{c}\text { Value } \\
\left(R \$ / m^{2}\right)\end{array}$ & $\begin{array}{c}\text { Area } \\
\left(m^{2}\right)\end{array}$ & $\begin{array}{c}\text { Value } \\
\left(R \$ / m^{2}\right)\end{array}$ \\
\hline Farmhouse & 130 & 944.43 & 130 & 1119.33 & 130 & 1119.33 & 200 & 1119.33 \\
Farm-hand accommodation & 60 & 737.59 & 100 & 737.59 & 100 & 737.59 & 100 & 737.59 \\
Feed store & 30 & 500.00 & 50 & 600.00 & 100 & 600.00 & 100 & 600.00 \\
Medication deposit & 10 & 500.00 & 15 & 600.00 & 15 & 600.00 & 20 & 600.00 \\
\hline
\end{tabular}

Source: Values defined by the authors based on construction costs estimated for the study region by the Goiás State Construction Industry Union (SINDUSCON-GO) in August 2015.

The use of a $60 \mathrm{hp}$ tractor and a trailer with a capacity of 4 tons was included in the calculations for the two most intensive systems (SCF and IPS). In all four systems, four horses were included in the budget as working animals.

The preparation of the soil for the establishment and maintenance of pasture was projected based on the direct recuperation method, given that the integration of pasture with crops or forest is not a common practice in the study region. Balieiro Neto et al. (2006) and Macedo et al. (2013) concluded that $90 \%$ of the soils used for pasture in Brazil present deficiencies of phosphorus, calcium, magnesium, zinc, and copper, and in the Cerrado region, toxic levels of aluminum and manganese are also found. This situation is further aggravated by inadequate management, which reduce the capacity of support of the pasture, as well as damaging the environment, resulting in losses for the producer, and society in general, over the short, medium, and long terms.
The application of nitrogenated fertilizers (together with lime) has proved effective for the recuperation and intensification of the production of the forage Brachiaria brizantha cv. Marandu on Cerrado soils, when applied in doses sufficient for the correction of the deficiencies highlighted by soil tests (PERON and EVANGELISTA, 2004; BALIEIRO NETO et al., 2006; COSTA et al., 2006; EUCLIDES et al., 2008). The expenditure on lime, fertilizers, herbicides, and the labor costs of the application of these products and pasture seeding were considered to be variable costs, while all other components of the budget were recorded as fixed costs. Except for the TRV system, the seeding and maintenance of the pasture was projected considering different levels of fertilization, with maintenance every two years for the whole area of pasture, and the application of herbicides for the control of invasive plants. In the specific case of the TRV system, pasture seeding and maintenance was projected in terms of the liming of the whole area of pasture (see Table 2) and manual weeding.

Table 2. Treatment of the soil for the seeding and maintenance of one hectare of pasture

\begin{tabular}{|c|c|c|c|c|}
\hline \multirow{2}{*}{ Product } & \multicolumn{4}{|c|}{ Quantity } \\
\hline & $T R V$ & PCS & SCF & IPS \\
\hline \multicolumn{5}{|l|}{ Seeding } \\
\hline B. brizantha Marandu seeds (kg) & 15 & 15 & 15 & 15 \\
\hline Lime $(\mathrm{kg})$ & 540 & 540 & 540 & 540 \\
\hline Superphosphate (kg) & & 90 & 90 & 90 \\
\hline Ammonium sulfate (21\% Nitrogen) (kg) & & 154.39 & 163.68 & 277.73 \\
\hline Potassium chloride (kg) & & 40 & 40 & 40 \\
\hline Herbicide (L) & & 3 & 3 & 3 \\
\hline Services (labor + equipment) (R\$) & 491.75 & 565.25 & 565.25 & 565.25 \\
\hline \multicolumn{5}{|l|}{ Maintenance } \\
\hline Lime $(\mathrm{kg})$ & 540 & 378 & 378 & 378 \\
\hline Superphosphate $(\mathrm{kg})$ & & 90 & 90 & 90 \\
\hline Ammonium sulfate (21\% Nitrogen) (kg) & & 154.39 & 163.68 & 277.73 \\
\hline Potassium chloride (kg) & & 40 & 40 & 40 \\
\hline Herbicide (L) & & 3 & 3 & 3 \\
\hline Services (labor + equipment) (R\$) & 141.75 & 215.25 & 215.25 & 215.25 \\
\hline
\end{tabular}

Source: Research data. 
The clearing (mowing, swathing, and removal of fine debris), preparation of the soil (harrowing and levelling, liming, application of herbicides and fertilizers), and mechanical seeding were all projected in terms of their labor costs (hourly or daily rates) and machinery rental (hourly rates), with fuel and maintenance costs also included.

In all four systems, the pasture was seeded with Brachiaria brizantha cv. Marandu, the predominant variety of grass planted in the Rio Vermelho basin, which renders $11.67 \%$ crude protein (dry mass) and $53.97 \%$ total digestible nutrients (TDN) in the rainy season, and $7.24 \%$ crude protein and $54.29 \% \mathrm{TDN}$ in the dry season (VALADARES FILHO et al., 2015).

As the same area of pasture was planted in all four systems, the estimates of the accumulation of dry mass $(\mathrm{DM} / \mathrm{kg} /$ day) necessary to feed the cattle took into account the consumption during the rainy season plus the quantity needed to defer its use during the dry season. The amount of fertilizer needed to guarantee the accumulation of forage necessary to satisfy the nutritional demands of the daily weight gain predicted for each production system was projected based on the reference values provided by Balieiro Neto et al. (2006).

The Nelore cattle breed was considered for the present study, given its predominance in Brazil, where it has adapted well to the local pastures, and has good resistance to disease, and ecto- and endoparasites (ABIEC, 2015), with vaccination once every six months, timed to coincide with the local foot-and-mouth vaccination campaigns.

The natural breeding season was planned for the period between November and February, when the greatest nutritional demands of the breeding cows coincides with the most productive period of forage, guaranteeing heavier calves, which are healthier and easier to manage (PAULINO et al., 2006).
For the low-technology extensive traditional system (TRV), the herd was composed of one bull (selected from the home herd) for every 25 cows. In the other three systems, the ratio was approximately one bull to every 30 cows, with genetically superior bulls being selected to ensure the improvement of the genetic constitution of the herd. The reproductive performance was improved through protein-based supplementation for dry and primiparous cows, in order to compensate for the lack of forage or its reduced nutritional value during the dry season, which precedes the breeding season.

Newborn Nelore calves were assumed to weigh an average of $32.30 \mathrm{~kg}$, based on the reference value provided by Chud et al. (2014), derived from a sample of 46,911 births, with a standard deviation of $3.80 \mathrm{~kg}$. The preparation of the supplementary diet for the calves in the IPS to ensure a daily weight gain was projected based on the production of $6.67 \mathrm{~kg}$ of milk per day, estimated by the model of Jenkins \& Ferrell, based on the function $y=5.9579+0.4230 . S \cdot e^{(-0.1204 .5)}$, for the period between 8.69 and 34.76 weeks, as determined by Henriques et al. (2011), considering that the calves are raised exclusively on their mothers' milk during the first two years of life. The supplements and fattening diet were prepared with the components listed in Table 3, configured using the free BR-Corte (2015) software, considering the prices and local availability of the different components, with the feed being prepared on each property.

Fixed labor costs included a single permanent farm-hand for the TRV system, two for the PCS, and three for the more intensive systems (SCF and IPS), with salaries equivalent to two minimum wages, with an additional $33 \%$ for social security payments, vacation pay, and annual bonuses.

The husbandry parameters listed in Table 4 were used to constitute the herd in the first year, with the

Table 3. Cost of feed and concentrates (October/2015 - R\$)

\begin{tabular}{l|c|cc|cc|cc}
\hline \multirow{2}{*}{ Feed } & \multirow{2}{*}{$\begin{array}{c}\text { Unit } \\
\text { price }\end{array}$} & \multicolumn{2}{c|}{ PCS } & \multicolumn{2}{c|}{ SCF } & \multicolumn{2}{c}{ IPS } \\
\cline { 3 - 8 } & & $\begin{array}{c}\text { Quantity } \\
(\mathrm{kg})\end{array}$ & $\begin{array}{c}\text { Total Cost } \\
(\mathrm{R} \$)\end{array}$ & $\begin{array}{c}\text { Quantity } \\
(\mathrm{kg})\end{array}$ & $\begin{array}{c}\text { Total Cost } \\
(\mathrm{R} \$)\end{array}$ & $\begin{array}{c}\text { Quantity } \\
(\mathrm{kg})\end{array}$ & $\begin{array}{c}\text { Total Cost } \\
(\mathrm{R} \$)\end{array}$ \\
\hline Sorghum silage & 0.09 & - & - & 18,249 & 1,642 & - & - \\
Maize meal & 0.47 & 48,862 & 22,77 & 122,407 & 57,041 & 385,432 & 179,612 \\
Soybean chaff & 1.10 & 16,418 & 18,06 & 24,982 & 27,48 & 172,073 & 189,281 \\
Urea & 1.80 & 4,123 & 7,422 & 5,486 & 9,874 & 6,056 & 10,9 \\
Total & & $\mathbf{6 9 , 4 0 4}$ & $\mathbf{4 8 , 2 5 1}$ & $\mathbf{1 7 1 , 1 2 3}$ & $\mathbf{9 6 , 0 3 7}$ & $\mathbf{5 6 3 , 5 6 2}$ & $\mathbf{3 7 9 , 7 9 3}$ \\
\hline
\end{tabular}

Source: Research data. 
Table 4. Husbandry parameters

\begin{tabular}{lcccc}
\hline \multicolumn{1}{c}{ Parameter } & TRV $^{(1)}$ & PCS $^{(2)}$ & SCF $^{(3)}$ & IPS $^{(4)}$ \\
\hline Birth rate (\%) & 60 & 80 & 80 & 90 \\
Pre-weaning mortality (\%) & 8 & 4 & 4 & 2 \\
Weaning rate (\%) & 55 & 75 & 75 & 88 \\
Mortality under 1 year of age (\%) & 4 & 2 & 2 & 1 \\
Mortality 1 to 2 years (\%) & 4 & 2 & 2 & 1 \\
Mortality above 2 years of age (\%) & 2 & 1 & 1 & 1 \\
Age at first breeding (months) & 48 & 35 & 35 & 30 \\
Birth interval (months) & 20 & 16 & 16 & 14 \\
Mean age at slaughter (months) & 42 & 30 & 24 & 18 \\
Slaughter rate (\%) & 20 & 22 & 22 & 35 \\
Mean carcass weight (kg) & 243 & 240 & 270 & 240 \\
Carcass yield (\%) & 53 & 54 & 56 & 54 \\
Stocking rate (AU/hectare) & $(5)$ & 3 & 3.0 & 5 \\
Replacement of females (\%) & 0.9 & 10 & 10 & 10 \\
Replacement of males (\%) & 10 & 12.5 & 12.5 & 12.5 \\
\hline
\end{tabular}

(1) Adapted from the Brazilian mean (EUCLIDES FILHO et al., 2001), with the parameters for the other systems proposed here being derived from the traditional ranching system of the middle Rio Vermelho basin, based on an extensive regime; (2) System based on low levels of concentrated supplementation, a semi-extensive regime, with the rotation of 13 fields; (3) System with low levels of concentrated supplementation and confinement for fattening. (4) Intensive Pasture System, with the whole herd being rotated among 20 pickets; (5) $\mathrm{AU}=450 \mathrm{~kg}$ of animal body weight.

Source: Research data.

equilibrium being maintained during the 15 years of the project, when the whole herd was sold off, with a residual value of one hundred percent. Ten percent of the breeding cows were discarded annually, being replaced by heifers from the local herd, with all the surplus heifers being sold. The stocking rate of the TRV system was estimated considering the composition of the herds of each municipality in the Rio Vermelho basin, according to the agricultural census (IBGE, 2006), applied to the herd present in these municipalities in 2014.

Higher birth rates were achieved in the more intensive production systems through the provision of improved nutrition, the acquisition of better quality, genetically-improved bulls, and the removal of cows with low rates of pregnancy. The highest birth rates and lowest mortality rates, as well as the reduced age at first breeding and short interbirth intervals in the more intensive rearing systems resulted in much larger herds. In the IPS system, creep feeding resulted in the weaning of heavier calves with an enhanced capacity for the assimilation of the diet during the productive cycle, reaching terminal weight early.

The linear depreciation method was used to calculate the residual value of the infrastructure, tractor and trailer, pasture seeding in the TRV system, breeding bulls and working animals. Depreciation of the pasture was projected only for the TRV system, considering 20 years of productive life and a residual rate of zero percent, with maintenance every five years, given the low technological input of this system. The fertilizer-based management in the remaining systems was estimated at two years, maintaining the productive capacity of the pasture, and thus with no projected depreciation.

Rural property tax (ITR) was estimated according to Federal Law 9393 of December 19 (1996), based on the specific characteristics of each system.

The prices of the inputs were based on those practiced in the municipalities of Goiás, Itapirapua, Jussara, and Matrincha, which account for $52 \%$ of the cattle found in the Rio Vermelho basin, and in Goiânia, for inputs not purchased locally, between August and October 2015. The acquisition price of the animals used to form the herds was based on normative ruling 39/15 of the Goiás State Inland Revenue Service, published on 19 October (2015), which determines the value of beef cattle for slaughter, adapted to the local characteristics of the region, to determine the ICMS (State Tax on Goods and Services). 
To calculate revenues, a cash price of 139 BRL per arroba (Brazilian measure of live weight equivalent to $15 \mathrm{~kg}$ ) was considered for beef steers and surplus bulls, and 132 BRL for surplus cows, with heifers of between 337 and $357 \mathrm{~kg}$ being priced at 1,800 BRL. These prices were published by Scot Consultants (2015) in Goiania, the region's physical market and practiced by the JBS meatpacking plant in Mozarlandia (Goiás).

\subsection{Economic}

The cash flow was structured considering fixed and variable costs, specified for each system, with receipts being generated solely by the sale of cattle. The separation of the total costs of producing beef in fixed costs (which do not vary with the volume produced) and variable costs (which vary according to productivity) permits a better evaluation of each element during the reproductive cycle. In the present study, a cycle of one year was considered.

The NPV was applied to assess whether the cash flow (receipts less costs) over the 15-year period, discounted at a rate of $6.17 \%$, would be sufficient to cover the investments in the productive system, thereby generating a profit. For the present study, a rate of financial discount equivalent to the Minimum Rate of Attractiveness (MRA) was adopted, and when the NPV was above zero, the project was considered to be economically viable, with an internal rate of return (IRR) above the MRA value (the capital opportunity cost), enabling the definition of the IRR, otherwise, the project was considered to be economically unviable (TARQUIM and BLANK, 2008).

For the evaluation of the projects, the IRR is compared with the MRA, which is equivalent to the interest on a savings account. If the IRR is higher than the inflation-adjusted (real) interest received on a savings account (6.17\% per annum), analyzed together with the value of the NPV, the project is considered to be economically viable, and can be implemented.

The gross margin (GM) represents the difference between gross receipts and effective operating costs (variable costs minus the remuneration of floating capital). This indicator assesses whether receipts are sufficient to cover variable costs with effective outlay. The greater the positive value of the GM, the greater the short-term economic sustainability of the project, given the productive infrastructure in operation.
The net margin (NM) is obtained from the difference between gross receipts and total operational costs (effective operational costs less depreciation), which demonstrates the capacity of the productive unit to obtain gross receipts that exceed the effective shortterm outlay and guarantee the replacement of capital (infrastructure, machinery, animals, pasture, and other items) over the long term, given the need to accumulate reserves to cover depreciation. In this case, the greater the positive value of the net margin, the greater economic sustainability over both the shot and the long terms. Profits are determined by the ratio between results and gross receipts, so the greater the positive percentage, the greater the profitability of the productive activity.

This study was based on the application of the NPV and IRR for the analysis of the economic viability of start-up (bare earth) beef cattle production in the Brazilian Cerrado savanna, which requires the reversal of capital for the implantation of the infrastructure need for the productive process, considering one system of extensive ranching, and three systems of intensive beef production. The same systems were also evaluated considering pre-existing infrastructure, evaluating short and long term economic sustainability, based on the GM, NM, and profitability rates.

The production of cattle by the more intensive systems is expected to maximize profits. The management potential, considering the different participants and variables of the productive process, and their respective interconnections, is expected to guarantee the continuous updating of the process and systematic decision-making that ensures continuity of production in line with the demands of the sector.

\section{Results and discussion}

The composition of each herd (Table 5) reflected the husbandry parameters of each system (Table 4), considering in particular the differences in nutrition, with low levels of supplementation during the dry season in the PCS and SCF systems, and supplementation throughout the year (dry and rainy seasons) in the IPS system. The number of breeding cows for the TRV system was determined by the mean number of cows at properties in the Rio Vermelho basin (total number of cows in the basin/number of properties). 
Table 5. Composition of the herds. The number of animals was rounded to the nearest unit

\begin{tabular}{lcccc}
\hline \multirow{2}{*}{ Category } & \multicolumn{3}{c}{ SYSTEM } & SCF \\
\cline { 2 - 5 } & TRV & PCS & 382 & 693 \\
\hline Cows & 103 & 343 & 13 & 18 \\
Bulls & 4 & 12 & 153 & 312 \\
Calves (0-8 months) & 31 & 137 & 150 & 309 \\
Calves (8-12 months) & 30 & 135 & 147 & 306 \\
Females (13-18 months) & 28 & 132 & 144 & \\
Females (19-24 months) & 27 & 129 & & 312 \\
Females (25-30 months) & 27 & & & 309 \\
Females (31-36 months) & 26 & & 153 & 306 \\
Calves (0-8 months) & 31 & 137 & 150 & \\
Calves (8-12 months) & 30 & 135 & 147 & \\
Males (13-18 months) & 28 & 132 & 144 & \\
Males (19-24 months) & 27 & 129 & & \\
Males (25-30 months) & 27 & 128 & & \\
Males (31-36 months) & 26 & & $\mathbf{1 5 8 2}$ & \\
Males (37-42 months) & 26 & $\mathbf{1 5 4 8}$ & & \\
Total (heads) & $\mathbf{4 7 1}$ & & & \\
\hline
\end{tabular}

Source: Research data.

Grazing was differentiated among the systems according to their distinct fertilization practices, with higher doses of nitrogenated compounds (Table 2) being applied in the more intensive systems. The supplementation projected for the SCF system (Table 3) was the same as that for the PCS, except for the 144 animals confined on the ranch during the final three months of the final fattening phase. The project included the sale of all the beef steers and $90 \%$ of the heifers in the final phase in each system, together with $10 \%$ of the breeding cows, with the least productive individuals being sent for slaughter.

The calves weaned at eight months in the more intensive systems, reflecting the better diet of the breeding cows and the concentrated supplementation (creep feeding) in the IPS system, as well as the improved genetic constitution of the bulls (Table 6).

In the TRV system, the breeding bulls were selected from the local herd, and remained on the property for only two years. In the other three systems, the bulls were replaced after a working lifespan of eight years, in order to maintain a high rate of reproduction. The different technological schemes resulted in the formation of larger herds, with heavier animal at weaning, which are able to attain their slaughter weight at much younger ages, leading to an acceleration in the input of receipts, a reduction in the production period and, as a consequence, in relative costs.
In the SCF system, the beef steers attain a greater slaughter weight due to the quality of the diet during the final three months of confinement, guaranteeing a better finish to the carcass. The total production of carcass in arrobas per hectare reflects the increase in productivity of the more intensive systems, which results in a greater total volume of carcass produced per hectare (38.98 arrobas per hectare in the TRV system, 177.99 in the PCS, 207.61 in the SCF, and 413.99 in the IPS). Considering the TRV system as the baseline, the increase in productivity was $357 \%$ in the PCS system, $433 \%$ in the SCF system, and $962 \%$ in the IPS.

In addition to the more intensive production, the systems based on a better quality diet are assumed to prepare animals for slaughter by an earlier age and produce beef of a higher quality, in terms of its tenderness and coloration (SCOLLAN et al., 2006; FELíCIO, 1997).

In terms of the investments for the installation of each of the four systems (Table 7), the traditional (TRV) system allocates $28 \%$ of the total investment to infrastructure, $57 \%$ to the acquisition of the herd and working animals, and $15 \%$ for pasture seeding.

The costs of clearing and preparing the soil, and seeding it with Brachiaria were all included in the item seeding the pasture, with the same monetary value being allocated to all the systems, given that the same area of pasture (331.47 ha) was planted in all cases. 
Table 6. Mean annual production of each system

\begin{tabular}{|c|c|c|c|c|c|c|}
\hline System & $\begin{array}{l}\text { Age at slaughter } \\
\text { (months) }\end{array}$ & $\begin{array}{c}\text { Weight at } \\
\text { weaning } \\
(\mathrm{kg})\end{array}$ & $\begin{array}{c}\text { Weight at } \\
\text { slaughter } \\
(\mathrm{kg})\end{array}$ & $\begin{array}{c}\text { Number of animals } \\
\text { slaughtered }\end{array}$ & $\begin{array}{l}\text { Total weight of } \\
\text { carcasses } \\
(@)\end{array}$ & $\begin{array}{l}\text { Carcass } \\
\text { (kg/ha) }\end{array}$ \\
\hline \multicolumn{7}{|l|}{ TRV } \\
\hline Steer & 42 & 171 & 500 & 24 & 416.68 & 18.86 \\
\hline Heifer & 36 & 155 & 357 & 24 & 280.68 & 12.70 \\
\hline Breeding cow & 156 & - & 450 & 10 & 154.21 & 6.98 \\
\hline Bull & 132 & - & 500 & 0.5 & 9.79 & 0.44 \\
\hline Total & - & - & 1.807 & 58 & 861.36 & 38.98 \\
\hline \multicolumn{7}{|l|}{ PCS } \\
\hline Steer & 30 & 202 & 453 & 128 & 2085.57 & 94.38 \\
\hline Heifer & 24 & 180 & 337 & 116 & 1305.99 & 59.10 \\
\hline Breeding cow & 144 & - & 450 & 34 & 514.69 & 23.29 \\
\hline Bull & 120 & - & 500 & 1.4 & 26.95 & 1.22 \\
\hline Total & - & - & 1740 & 278 & 3933.20 & 177.99 \\
\hline \multicolumn{7}{|l|}{ SCF } \\
\hline Steer & 24 & 202 & 471 & 144 & 2529.91 & 114.49 \\
\hline Heifer & 24 & 180 & 337 & 129 & 1454.58 & 65.82 \\
\hline Breeding cow & 144 & - & 450 & 38 & 573.24 & 25.94 \\
\hline Bull & 120 & - & 500 & 1.6 & 30.02 & 1.36 \\
\hline Total & - & - & 1758 & 312 & 4587.75 & 207.61 \\
\hline \multicolumn{7}{|l|}{ IPS } \\
\hline Steer & 18 & 222 & 452 & 306 & 4975.89 & 225.17 \\
\hline Heifer & 18 & 190 & 337 & 275 & 3091.59 & 139.90 \\
\hline Breeding cow & 144 & - & 450 & 69 & 1040.01 & 47.06 \\
\hline Bull & 120 & - & 500 & 2.2 & 40.85 & 1.85 \\
\hline Total & - & - & 1739 & 650 & 9148.34 & 413.99 \\
\hline
\end{tabular}

The heifers were sold by the head and all other animals by the arroba $(15 \mathrm{~kg})$, sold directly to the meatpacking plants.

Source: Research data.

Table 7. Investments (R\$)

\begin{tabular}{lcccccccc}
\hline \multicolumn{1}{c}{ Investment } & TRV (R\$) & Part. (\%) & PCS (R\$) & Part. (\%) & SCF (R\$) & Part. (\%) & IPS & Part. (\%) \\
\hline Infrastructure & 356,196 & 28 & 640,509 & 20 & 780,91 & 23 & 876,994 & 18.6 \\
Fencing & 102,932 & 8 & 161,596 & 5 & 161,596 & 5 & 172,534 & 4 \\
Ranch house & 122,776 & 10 & 145,513 & 5 & 145,513 & 4 & 223,866 & 5 \\
Farm-hand accomodation & 44,255 & 3 & 147,518 & 5 & 221,277 & 7 & 221,277 & 5 \\
Storage & 20 & 2 & 39 & 1 & 69 & 2 & 72 & 2 \\
Corral & 22,372 & 2 & 71,317 & 2 & 71,317 & 2 & 71,317 & 2 \\
Drinking troughs & 20,061 & 2 & 41,715 & 1 & 50,058 & 1 & 49 & 1 \\
Watering hole & 22 & 2 & 28 & 1 & 35 & 1 & 40 & 1 \\
Feeding troughs & 1,8 & 0 & 5,85 & 0 & 11,25 & 0 & 27 & 1 \\
Stockyards & - & 0 & - & 0 & 15,899 & 0 & - & 0 \\
Tractor + trailer & - & 0 & - & 0 & 98 & 3 & 98 & 2.1 \\
Herd* & 729,63 & 57 & $2,314,947$ & 74 & $2,327,026$ & 68 & $3,551,813$ & 75.2 \\
Pasture & 194,076 & 15 & 194,076 & 6 & 194,076 & 6 & 194,076 & 4.1 \\
Total & $\mathbf{1 , 2 7 9 , 9 0 1}$ & $\mathbf{1 0 0}$ & $\mathbf{3 , 1 4 9 , 5 3 2}$ & $\mathbf{1 0 0}$ & $\mathbf{3 , 4 0 0 , 0 1 2}$ & $\mathbf{1 0 0}$ & $\mathbf{4 , 7 2 0 , 8 8 3}$ & $\mathbf{1 0 0}$ \\
\hline
\end{tabular}

* Cattle and working animals.

Source: Research data. 
The costs of fertilizing, liming, and the application of herbicides were included in the variable maintenance costs of each system (see Table 2).

For the PCS system, it was necessary to apply $20 \%$ of the total investment in infrastructure, $74 \%$ for the acquisition of cattle and working animals, and 6\% for seeding pasture. The SCF system demanded slightly more investment in infrastructure $(23 \%)$ in comparison with the PCS due to the specific type of stockyard required for this system, as well as the acquisition of a tractor and trailer (3\%) and the cattle (68\%), while pasture seeding accounted for $6 \%$. For the most technologically intensive system (IPS), 19\% of the total investment was allocated to infrastructure, $2 \%$ to the acquisition of the tractor and trailer, $75 \%$ to the purchase of animals, and $4 \%$ for the seeding of the pasture.

In all the systems, then, the acquisition of the herd represented the greatest proportion of the outlay. In practice, however, the formation of the herd is a gradual process, permitting adaptations, including the contribution of the original breeding cows, until the desired equilibrium is achieved.

The cash flow (Table 8) was structured considering the values of the first year as constants for all other

Table 8. Cash flow in the four systems (R\$)

\begin{tabular}{|c|c|c|c|c|}
\hline \multirow{2}{*}{ Item } & \multicolumn{4}{|c|}{ Cash flow (R\$) - 1st year } \\
\hline & $T R V$ & PCS & SCF & IPS \\
\hline 1. Fixed costs & 51,978 & 93,528 & 107,198 & 243,616 \\
\hline 1.1. Depreciation & 23,43 & 32,478 & 46,148 & 62,566 \\
\hline 1.1.1. Infrastructure & 13,086 & 24,032 & 29,164 & 33,693 \\
\hline 1.1.2. Machinery and equipment & - & - & 7650 & 7650 \\
\hline 1.1.3. Cattle and working animals & 640 & 8445 & 9333 & 21,222 \\
\hline 1.1.4. Pasture (Seeding) & 9704 & - & - & - \\
\hline 1.2. Remuneration of the land & - & - & - & - \\
\hline 1.3. Remuneration of the producer & 24 & 60 & 60 & 180 \\
\hline 1.4. Rural property tax (ITR) & 4548 & 1051 & 1051 & 1051 \\
\hline 1.5. Remuneration of the capital invested & - & - & - & - \\
\hline 2. Variable costs & 53,264 & 261,401 & 378,97 & 737,246 \\
\hline 2.1. Feed & 14,563 & 161,114 & 209,934 & 532,634 \\
\hline 2.1.1. Pasture (maintenance) & 5873 & 84,866 & 85,337 & 104,334 \\
\hline 2.1.3. Mineral supplements & 8690 & 27,997 & 28,559 & 48,508 \\
\hline 2.1.4. Sorghum silage & - & - & 1642 & - \\
\hline 2.1.5. Concentrates & - & 48,251 & 94,396 & 379,793 \\
\hline 2.2. Vaccines & 1416 & 5274 & 5593 & 9257 \\
\hline 2.3. Vermifuges/other medication & 1616 & 5874 & 6193 & 10,057 \\
\hline 2.4. Wages + additional costs & 25,153 & 50,306 & 75,459 & 75,459 \\
\hline 2.5. General services + accountant & 650 & 1900 & 1900 & 2176 \\
\hline 2.6. Other costs & 8272 & 17,559 & 21,082 & 24,739 \\
\hline 2.7. Fuel and lubricants & - & - & 34,6 & 34,6 \\
\hline 2.8. Acquisition of bulls & - & 11,552 & 12,866 & 26,26 \\
\hline 2.9. Remuneration of floating capital & 1594 & 7823 & 11,341 & 22,063 \\
\hline Total costs $(1+2)$ & 105,242 & 354,93 & 486,168 & 980,862 \\
\hline 3. Receipts & 125,912 & 569,696 & 664,576 & $1,329,997$ \\
\hline 3.1. Sale of beef steers & 57,918 & 289,894 & 351,657 & 691,649 \\
\hline 3.2. Sale of cows & 20,356 & 67,939 & 75,668 & 137,282 \\
\hline 3.3. Sale of heifers & 42,455 & 209,269 & 233,078 & 495,388 \\
\hline 3.4. Disposal of bulls & 5183 & 2595 & 4173 & 5678 \\
\hline 4. Investment $\left({ }^{*}\right)$ & $-1,279,901$ & $-3,149,532$ & $-3,400,012$ & $-4,720,883$ \\
\hline 5. Residual values at the end of the project & 909,661 & $2,733,060$ & $2,836,291$ & $4,107,711$ \\
\hline 6. Results (Receipts - total costs) & 20,67 & 214,766 & 178,409 & 349,135 \\
\hline 7. Effective operational costs & 51,67 & 253,579 & 367,628 & 715,182 \\
\hline 8. Total operational costs & 75,1 & 286,056 & 413,776 & 777,748 \\
\hline
\end{tabular}

Source: Research data. 
periods, with the investments and residual values being included in the 15th year, the final year of the project.

The contribution of fixed costs to total costs decreased considerably between the extensive system, TRV (49.39\%), and the technologically most intensive systems, reaching $26.35 \%$ in the case of the PCS system and $22.05 \%$ in the SCF system. This reduction in the relative contribution of fixed costs is expected, given the increasing input of variable items, in particular feeds. Even so, the IPS, which was the technologically most intensive system, was intermediate in the proportion of fixed costs $(24.84 \%)$. This resulted from the fact that the annual remuneration of the producer in this system was significantly higher than the others $(650 \%$ greater than the TRV system and $200 \%$ in comparison with the PCS and SCF).

In this case, it was decided to consider the returns on investments as being equivalent to the MRA, which would cover the opportunity cost of the use of the land, which is why the remuneration of the land was counted as zero for all the systems. While the size of the properties was the same in all cases, the rural property tax (ITR) was highest for the TRV system due to the reduced degree of utilization $(73 \%)$ in comparison with the other systems.

The variable costs of the intensive systems (73.65$77.95 \%$ ) were much higher in the intensive systems in comparison with the TRV (50.61\%), due to their larger herds and greater feeding costs (concentrates, sorghum silage, and mineral supplementation, as well as the higher dosage of nitrogen for the maintenance of the pasture). The item "other costs" also increased with the increasing technological intensification of the systems, given the inclusion in this item of taxes and additional expenditures related to trading costs, electricity, telephones, and the repair and maintenance of installations and infrastructure.
The depreciation of pastures was estimated only for the TRV system given that, in this case, the soil is only limed once every five years. In the other systems, the soil is limed every two years, and is also fertilized and treated with herbicides, in which case, the fertility of the soil is assumed to remain stable, and the Brachiaria, to reproduce naturally. It is important to note that soil analyses are essential to determine the adequate dosing of fertilizers, although conservative estimates of the quantities needed for typical Cerrado soils (Table 2), given the need to accumulate dry mass $(\mathrm{DM} / \mathrm{kg} /$ day) in each system.

The higher technological level of the more intensive systems, together with the adequate management of the soil, pasture, and animals, resulted in a larger herd, with reduced age at slaughter, and thus higher productivity, with greater receipts per hectare (Table 9), the greater the level of input. In comparison with the least intensive system, the TRV, the other systems presented an increase in receipts of $352.46 \%$ (PCS), $427.81 \%$ (SCF), and $956.29 \%$ (IPS), while total costs per hectare increased $237.25 \%, 361.95 \%, 832.01 \%$, respectively. Overall, then, the growth in receipts outstripped that of costs.

The effective operational costs are equivalent to the outlay of the producers, and are obtained by subtracting the remuneration of the floating capital from total variable costs. Total operational costs are calculated by adding the depreciation to the effective operational costs. These costs must be covered by receipts to guarantee the continuity of the activity over the short and long terms.

In the case of established systems, the analysis of gross and net margins (Table 10) indicate that all the beef production systems are economically sustainable over both the short and long terms, considering that the gross receipts were higher than total and effective operational costs, reflecting the potential for the

Table 9. Receipts from the sale of cattle

\begin{tabular}{c|cc|cc|c|c}
\hline \multirow{2}{*}{ System } & \multicolumn{2}{|c|}{ Gross receipts } & \multicolumn{2}{c|}{ Total Cost } & \multirow{2}{*}{$\begin{array}{c}\text { Effective Operational } \\
\text { Cost (R\$) }\end{array}$} & $\begin{array}{c}\text { Total Operational } \\
\text { Cost (R\$) }\end{array}$ \\
\cline { 2 - 5 } & $R(\$)$ & $(R \$ / h a)$ & $R \$$ & $(R \$ / h a)$ & $51,670.06$ & $75,099.72$ \\
TRV & $125,912.31$ & 379.86 & $105,242.22$ & 317.50 & $242,026.75$ & $274,504.28$ \\
PCS & $569,696.06$ & $1,718.70$ & $354,929.63$ & $1,070.77$ & $367,628.20$ & $413,775.78$ \\
SCF & $664,576.49$ & $2,004.94$ & $486,167.73$ & $1,466.70$ & $715,182.32$ & $777,747.95$ \\
IPS & $1,329,996.72$ & $4,012.42$ & $980,861.94$ & $2,959.13$ & \\
\hline
\end{tabular}

Source: Research data. 
Table 10. Indicators of economic efficiency

\begin{tabular}{lcccc}
\hline \multirow{2}{*}{\multicolumn{1}{c}{ Indicators }} & \multicolumn{5}{c}{ Systems } \\
\cline { 2 - 5 } & TRV & PCS & SCF & IPS \\
\hline NPV (R\$) & $-710,805.05$ & $26,682.43$ & $-530,970.50$ & $305,946.84$ \\
IRR (\%) & $-0.36^{*}$ & 6.26 & 4.45 & 6.87 \\
Gross margin (R\$) & $74,242.24$ & $327,669.31$ & $296,948.30$ & $614,814.40$ \\
Net margin (R\$) & $50,812.59$ & $295,191.78$ & $250,800.72$ & $552,248.77$ \\
Profitability (\%) & 16.42 & 37.70 & 26.85 & 26.25 \\
\hline
\end{tabular}

* The real positive value of the IRR was considered for the evaluation of the projects, although in this case, a negative value was used only to ratify the project's lack of economic viability already confirmed by its negative NPV. The TRV system would return a positive IRR value $(0.10 \%)$ if the remuneration of floating capital, and the investments in water holes, drinking troughs, and store sheds were excluded from the calculations.

Source: Research data.

replacement of the infrastructure, herd and working animals, machines and equipment, and pasture, in the case of the TRV system.

Estimated profitability (gross results divided by receipts) showed that, for every 100 BRL in gross receipts, the TRV producer obtains a profit of approximately 16 BRL. Of the more intensive systems, the PCS was the most profitable, followed by the IPS, and then the SCF. However, analyzing the economic viability of each production system, as a start-up (bare earth) with results corrected for interest $(6.17 \%$ per annum, after inflation), the present value obtained exceeded investments only in the PCS and IPS systems. The IRR of these two systems exceeded the minimum rate of attractiveness (MRA), confirming their economic viability.

Given the low estimates for its husbandry parameters (based on its low levels of technological input), the traditional local ranching system (TRV) had a smaller herd, sent older animals to slaughter, and thus had more limited results which, when converted to present values, did not exceed the predicted investments, as confirmed by the negative NPV and IRR lower than the MRA.

It is important to note that the TRV is economically unviable, even when the investment in artificial water sources (ponds and drinking troughs) is excluded from the budget. This adjustment reflects the typical practice in the region, where the cattle drinks at natural watercourses or reservoirs, and few producers invest in drinking troughs or artificial watering holes. This creates certain problems in the context of the current environmental legislation, however. Investment in these items was thus prioritized in the present, given the recently decreed Brazilian Forest Code (2012), which demands that "the margins of any natural watercourse, perennial or intermittent $[\ldots]$ ", according to the limits established in its 4th article, be maintained as areas of permanent preservation that cannot be used for productive activities.

The acquisition of the whole herd at the beginning of the project represents the equivalent of $57 \%$ of the total investment, contradicting the more traditional practice of allowing the herd evolve over time until achieving the desired equilibrium. This would account for the participation of new producers in this system, even though it is economically unviable.

The SCF system, while having a more advanced level of technology than that of the PCS system, had a negative NPV and IRR lower than its MRA, reflecting its lack of economic viability. Comparing the increase in costs $(131,238.10 \mathrm{BRL})$ and receipts $(94,880.43 \mathrm{BRL})$ of the two systems, while fattening in confinement was more efficient in terms of productivity, it was not more efficient economically. Even so, the variation in the price of feeds, or even the use of alternative types of ration, should be evaluated in more detail, given that this component represents a major proportion of the costs of confining the animals for fattening.

\section{Final considerations}

The present analysis of the four beef production systems indicates that the market forces which favor the increase in the efficiency of the system present considerable challenges to the participation of newcomers to the sector, given the limitations of 
economic and environmental sustainability, which require increased inversion of capital, reflecting the need for investments for the establishment of basic infrastructure, including pasture, to initiate the productive cycle.

The PCS and IPS projects, as proposed in the present study, were economically viable, given the flow of results, over a period of 15 years, given that the present value covers the investments in the system, and that the IRR exceeds the MRA, which is equivalent to the savings rate. These systems are thus economically and productively efficient, even when the whole project requires implantation as a start-up.

The TRV and SCF systems were economically unviable, however, given the negative NPV and the IRR, which was lower than the MRA. In the case of the SCF system, while production was relatively efficient, the project was not economically effective, in comparison with the other intensive systems.

Once each system was established, however, they generated receipts that exceeded their effective and total operational costs, thereby covering total outlay and depreciation over the year, over both the short and long-terms. In other words, they present positive gross and net margins, as well as profitability of above $16 \%$, although the IPS system had the highest gross and net margins, followed by the PCS, SCF and TRV systems.

The more efficient production of the three technologically intensive systems generated higher rates of productivity per hectare. However, the system based on the low consumption of concentrated supplements (PCS) resulted in the highest profitability rate $(38 \%)$ of the three intensive systems.

\section{References}

ABIEC - Associação Brasileira das Indústrias Exportadoras de Carne. Rebanho bovino brasileiro. Brazilian cattle herd. Available at: < http://www.abiec. com.br/3_rebanho.asp >. Accessed: March 10, 2015.

AGRODEFESA. Agência Goiana de Defesa Agropecuária. Dados dos Estabelecimentos do SIE de Goiás. [Data on the SIE (inspected) establishments in Goiás] Goiania, Goiás (Brazil). Available at: < http:// www.agrodefesa.go.gov.br/cadastro-e-convenios $>$. Accessed: July 30, 2015.

ANDRADE, R. G. et al. Indicativo de pastagens plantadas em processo de degradação no bioma
Cerrado. [Role of seeded pasture in the degradation of the Cerrado biome] In: Remote Sensing Brazilian Symposium, João Pessoa, PB (Brazil). Anais... João, PB: INPE, 2015. Available at: <http://www.dsr.inpe. br/sbsr2015/files/p0300.pdf $>$. Accessed: November 12, 2015.

ARAUJO, H. S. et al. Aspectos econômicos da produção de bovinos de corte. [Economic aspects of the prodution of beef cattle]. Pesquisa Agropecuária Tropical, Universidade Federal de Goiás, Goiânia, v. 42, p. 82-89, 2012.

ARMENTERAS, D., RODRÍGUEZ, N. and RETANA, J. Landscape dynamics in northwestern Amazonia: an assessment of pastures, fire and illicit crops as drivers of tropical deforestation. Plos One, 2013. DOI: 10.1371/ journal.pone.0054310.

BALIEIRO NETO, G. et al. Recuperação e intensificação da produção de pasto de "Urochloa Brizantha" Stapf Webster cv. Marandu. [Recuperation and intensification of the production of "Urochloa Brizantha" Stapf Webster cv. Marandu pasture]. Revista Pesquisa \& Tecnologia, Campinas, SP, 2006.

BELLAVER, C. and BELLAVER, I. H. Livestock production and quality of societies' life in transition economies. Livestock Science, v. 59, p. 125-135, 1999. DOI: 10.1016/S0301-6226 (99) 00021-4

BRAZIL. Lei n. 9393, de 19 de dezembro de 1996. Poder Executivo. Dispõe sobre o Imposto sobre a Propriedade Territorial Rural - ITR, sobre pagamento da dívida representada por Títulos da Dívida Agrária e dá outras providências. [On the Rural Property Tax - ITR, on the payment of debts on agricultural titles and other measures] Available at: <http://www.planalto.gov. br/ccivil_03/LEIS/L9393.htm>. Accessed: October 25, 2015.

. Lei no 12651, de 25 de maio de 2012. Poder Executivo. Dispõe sobre o Código Florestal Brasileiro e dá outras providências. [Executive powers: Brazilian Forest Code and other measures] Available at: <http:// www.planalto.gov.br/ccivil_03/_ato2011-2014/2012/lei/ 112651.htm > . Accessed: December 20, 2015.

BR-CORTE 2. Formulação de dieta e predição de desempenho, 2015. Software livre. [Formulation of the diet and prediction of performance]. Universidade Federal de Viçosa MG. Available at: <www.brcorte.com.br/>. Aceessed: July 7, 2015.

CHUD, T. C. S. et al. Genetic analysis for gestation length, birth weight, weaning weight, and accumulated productivity in Nellore beef cattle. Livestock Science, v. 170, p. 16-21, 2014. DOI:10.1016/j.livsci.2014.09.024. 
COSTA, K. A. P., OLIVEIRA, I. P. and FAQUIN, V. Adubação nitrogenada para pastagens do gênero Brachiária $\mathrm{em}$ solos do Cerrado. [Nitrogenated fertilization for Brachiaria pasture on Cerrado soils]. Embrapa Arroz e Feijão. Santo Antônio de Goiás GO, 2006. (Document 192).

DILL, M. D. et al. Factors affecting adoption of economic management practices in beef cattle production in Rio Grande do Sul state, Brazil. Journal of Rural Studies, v. 42, p. 21-28, 2015. DOI:10.1016/j.jrurstud.2015.09.004.

EUCLIDES FILHO, K. Interação de bovinos de corte e o trinômio genótipo-ambiente-mercado na produção de carne bovina nos trópicos. [Interaction between beef cattle and the genotype-environment-market triped in the production of beef in the tropics]. In: Simpósio de Produção de Gado de Corte [Symposium On Beef Cattle Production], v. 2, p. 93-115. Viçosa. Anais... [Annals] Viçosa: UFV/DZO, 2015.

EUCLIDES, V. P. B. et al. Produção de forragem e características da estrutura do dossel de cultivares de Brachiaria brizantha sob pastejo. [Production of forage and the characteristics of the tufts of Brachiaria brizantha under grazing]. Embrapa Gado de Corte, Campo Grande-MS, v. 43, p. 1805-1812, 2008.

FELEMA, J., RAIHER A. P. and FERREIRA, C. R. Agropecuária brasileira: desempenho regional e determinantes de produtividade. [Brazilian agriculture: regional performance and determinants of productivity]. Revista Economia e Sociologia Rural, Brasilia, v. 51, p. 555-573, 2013.

FELICIO, P. E. Fatores que influenciam na qualidade da carne bovina. [Factors that influence the quality of beef]. In: PEIXOTO, A. M., MOURA, J. C. and FARIA, V. P. (Eds.). Produção de novilho de corte. [Production of beef calves] Piracicaba-SP (Brazil): FEALQ, 1997.

FERREIRA, L. G., ARANTES, A. E. and SOUSA, S. B. Radiografia das pastagens do Brasil (Relatório final), 2014. [Radiography of Brazilian pastures, final report] Universidade Federal de Goiás. Available at: <www. pastagem.org >. Accessed: October 10, 2015.

GARAGORRY F. L., QUIRINO, T. R. and SOUSA, C. P. Diagnóstico sociotécnico da agropecuária brasileira II. Estabelecimentos. [Sociotechnical diagnosis of Brazilian agriculture II. Establishments] Embrapa Informação Tecnológica, Brasília DF, 2002. (Documents 3).

GOIAS. Secretaria da Fazenda Estadual. Instrução Normativa 39, 2015 october 19. Dispõe sobre a atualização dos valores correntes de bovinos para abate para efeito de base de cálculo do ICMS. [Updates on the present value of beef cattle for the calculation of the ICMS tax] Available at: < http://www.sefaz.go.gov.br/> Accessed: October 30, 2015.

HENRIQUES, L. T. et al. Avaliação de modelos não-lineares $e$ da relação do consumo voluntário de vacas primíparas e de bezerros com a curva de lactação de vacas Nelores. [Evaluation of non-linear models and the relationship between the voluntary feeding of primiparous cows and calves with the lactation curve in Nelore cattle] Revista Brasileira de Zootecnia, Viçosa MG, v. 40, p. 1287-1295, 2011.

IBGE - Instituto Brasileiro de Geografia e Estatística. Economia. Censo agropecuário, 2006. [Farming census, 2006] Available at: <http://www.ibge.gov.br/home/ estatistica/economia/agropecuaria/censoagro/default. shtm >. Accessed: 5 March, 2015.

Pesquisa da Pecuária Municipal. Efetivo dos rebanhos 2013-2014. [Brazilian Institute of Geography and Statistics - Municipal Livestock Census 20132014]. Available at: < http://www.ibge.gov.br/home/ estatistica/economia/ppm/2014/default.shtm >. Accessed: October 25, 2015.

MACEDO, M. C. M. et al. Degradação de pastagens, alternativas de recuperação e renovação, e formas de mitigação. [Degradation of pastures, alternative for recuperation and renovation, and strategies for mitigation]. In: Encontro de adubação de pastagens Scot Consultoria [Scot Consultants meeting on pasture fertilization] TEC - FÉRTIL, 1. Ribeirão Preto SP, 2013. Anais... [Annals] Bebedouro: Scot Consultoria. Available at: <https://www.alice.cnptia.embrapa.br/ alice/handle/doc/976514> . Accessed: july 18, 2015.

MACHADO, L. E. G. and LIMA, C. V. L. Compartimentação geomorfológica da bacia hidrográfica do Rio Vermelho GO (Brazil), utilizando imagens ASTER. [Geomorphological divisions of the Rio Vermelho hydrographic basin in Goiás, Brazil, using ASTER images]. In: Simpósio Brasileiro de Sensoriamento Remoto - SBSR. Curitiba PR. Anais... São Paulo SP, Instituto Nacional de Pesquisa Espacial, 2011.

MAPA - Ministério da Agricultura, Pecuária e Abastecimento. Projeções do agronegócio: Brasil 2013/2014 a 2023/2024 - projeções de longo prazo. [Predictions of agribusiness growth, Brazil 2013/2014 to 2023/2024 long term trends] Brasília DF, 2014.

. Inspeção Sanitária e Industrial de Produtos de Origem Animal em Goiás. Relatório de abate de bovinos dos municípios da Bacia do Rio Vermelho, 2015. [Report on the slaughter of cattle in the municipalities of the 
Rio Vermelho basin] Goiânia GO (Brazil). Available at: $<$ http://www.agricultura.gov.br/animal/frigorificos $>$. Accessed: August 10, 2015.

MARTHA JÚNIOR, G. B. and VILELA, L. Pastagens no Cerrado: baixa produtividade pelo uso limitado de fertilizantes. [Pastures in the Cerrado: low productivity resulting from the limited use of fertilizers]. Embrapa Cerrado, Planaltina DF, 2002. (Document 50).

MARTINS, C. D., KICHEF, A. N. and CORREA, E. S. Análise econômica de sistemas de produção de gado de corte no Mato Grosso do Sul. [Economic analysis of the beef cattle production systems of Mato Grosso do Sul]. Revista de Estudos Sociais, Cuiabá MT, v. 4, p. 27-47, 2002.

MAZZETTO, A. M. et al. Improved pasture and herd management to reduce greenhouse gas emissions from a Brazilian beef production system. Livestock Science, v. 175, p. 101-112, 2015. DOI: 10.1016/j.livsci.2015.02.014.

OECD-FAO. Overview of the OECD-FAO Agricultural outlook 2015-2024, 2015. Available at: <http:// www.keepeek.com/Digital-Asset-Management/ oecd/agriculture-and-food/oecd-fao-agriculturaloutlook-2015/overview-of-the-oecd-fao-agriculturaloutlook-2015-2024_agr_outlook-2015-4-en\#page23>. Accessed: November 11, 2015.

PALACÍN, L. and MORAES, M. A. S. História de Goiás (1722-1972). [History of Goiás, 1722-1972] 7. ed. Goiânia GO: Ed. Vieira, 2008.

PAULINO, M. F. et al. Bovinocultura de precisão em pastagens. [Precision cattle production on pasture]. Simpósio de Produção de Gado de Corte, v. 5, p. 361-412, 2006.

PERON, A. J. and EVANGELISTA, A. R. Degradação de pastagens em regiões de cerrado. [Degradation of pasture in the Brazilian Cerrado]. Revista Ciência e Agrotecnologia, Lavras, MG, v. 28, p. 655-661, 2004.

ROBINSON, T. P. et al. Mapping the Global Distribution of Livestock. Plos One, 2014. DOI: 10.1371/journal. pone.0096084.

SANTOS, P. S. Caracterização e mapeamento biofísico ambiental da Bacia Hidrográfica do Rio Vermelho a partir de dados remotamente sensoriados. Doctoral dissertation,
Instituto de Geografia/UFG. Goiânia GO, 2014. Available at: < https://repositorio.bc.ufg.br/tede/handle/ tede/4084?locale=pt_BR>. Accessed: March 2, 2015.

SCOLLAN, N. et al. Innovations in beef production systems that enhance the nutritional and health value of beef lipids and their relationship with meat quality. Meat Science, 2006. doi:10.1016/j.meatsci.2006.05.002.

SCOT CONSULTORIA. Cotações boi gordo, 2015. [Beef prices] Available at: <https://www.scotconsultoria. com.br/cotacoes/>. Accessed: October 30, 2015.

SILVA, R. O. et al. Increasing beef production could lower greenhouse gas emissions in Brazil if decoupled from deforestation. Nature Climate Change, 2016. DOI: 10.1038/NCLIMATE2916.

SIMÕES, A. R. P., MOURA, A. D. and ROCHA, D. T. Avaliação econômica comparativa de sistemas de produção de gado de corte sob condições de risco no Mato Grosso do Sul. [Comparative economic evaluation of the beef cattle production systems under conditions of risk in Mato Grosso do Sul]. Revista de Economia e Agronegócio, Viçosa-MG, 2007. Available: <http://www. rea.ufv.br/index.php/rea/article/view/97>. Accessed: September 18, 2015.

TARQUIM, A. and BLANK, L. Engenharia econômica. [Economic engineering] 6. ed. São Paulo-SP: Ed. McGraw-Hill, 2008.

VALADARES FILHO, S. C. et al. CQBAL 3.0. Tabelas brasileiras de composição de alimentos para bovinos, 2015. [Brazilian tables of the composition of feeds for cattle] Available at: <www.ufv.br/cqbal>. Accessed: July 12, 2015.

VEIGA, A. M. et al. Caracterização hidromorfológica do Rio Vermelho. [Hydromorphological characteristics of the Rio Vermelho] XI Simpósio de Recursos Hídricos do Nordeste. [Symposium of the Hydrological Resources of the Brazilian Northeast] João Pessoa-PB, 2012.

VIEIRA, P. A. Dinâmica de ocupação, vulnerabilidade e cenários para a Bacia Hidrográfica do Rio Vermelho, Goiás (Brazil). [Dynamics of the occupation, vulnerability and landscapes of the hydrographic basin of the Rio Vermelho in Goiás, Brazil] Doctoral dissertation, CIAMB/UFG. Goiânia, 2013.

Todo o conteúdo deste periódico, exceto onde estiver identificado, está licenciado sob uma Licença Creative Commons (cc by 4.0). 